\title{
VALUES SUITABLE IN CRISIS MANAGEMENT: A STUDY AMONG UNIVERSITY STUDENTS
}

\author{
Sonia Agut, Francisco Lozano, Raquel Agost \\ Dept. of Psychology. Universitat Jaume I (SPAIN)
}

\begin{abstract}
Values are broad goals that vary in importance as guiding principles in life of people. Two types are distinguished: collectivistic and individualistic values. They differ on their emphasis on a collective or personal self, if personal goals are considered more or less important than the group goals, and the extent to which social norms or individual attitudes should determine behavior (e.g., Triandis, 1995). Values that serve individualistic interests are ambition or pleasure, while values that serve collectivistic interests are, for instance, responsibility or helpfulness. Traditionally, research on gender issues has displayed that the values that serve to collectivistic interests are consistent with the traditional feminine gender role, while the values that serve to individualistic interests are consistent with the traditional masculine role. In addition, stereotypically female values are not congruent with the values traditionally associated to leadership positions (Cuadrado, 2004). The masculine ones seem to be more suitable. As result, women may have difficulties to achieve leadership jobs in comparison with men (think manager-think male). However, when we think about a company which is performing poorly, that is to say, is in a crisis situation, which values are preferred in the leader, the masculine or the feminine ones?
\end{abstract}

The aim of this study is to analyze which values are considered more suitable in a leader in an organization which is facing a crisis and also to explore the gender differences in this topic. The sample was composed of 240 Spanish university students ( $n=96$ men and $n=144$ women). The results show that participants consider that both individualistic (e.g., success) and collectivistic (e.g., responsibility) values have similar relevance in a leader of a crisis organization. In addition, for male and female participants individualistic values have similar importance. In the case of collectivistic values, there are gender differences. Female students in comparison with male students perceive those values more important in a leader in a crisis company. The implications of the results for education considering that values guide social attitudes, future research guidelines, and limitations of the study are also discussed.

Keywords: Individualistic and collectivist values, management, crisis, university students.

\section{INTRODUCTION}

Women have joined massively both the labour market and the education system, especially during the second half of the twentieth century. However, from a transversal perspective, their situation is not analogous to men position. This is reflected in the difficulty of many women to fully develop a professional career that allows them reach top management positions, since there is the so-called glass ceiling that prevents them from getting there. Gender stereotypes and the perceived incongruity between the leadership role in these contexts and female gender role is one of the main mechanisms that helps to understand the existence of glass ceiling. Also, personal values play an important role. Research on gender issues has displayed that the values that serve to collectivist interests are consistent with the traditional feminine gender role, while the values that serve to individualistic interests are consistent with the traditional masculine role. In addition, stereotypically female values seem not congruent with the values traditionally associated to leadership positions [1].

Moreover, when they finally reach upper management positions, still copes with another form of discrimination, the so-called glass cliff 2]. It alludes to the fact that women are often appointed to positions that are more precarious, and associated with a higher risk of failure than those occupied by men [2, 3, 4 In this case, gender stereotypes benefit women. Communal attributes may appear to be a better fit to deal with the socioemotional challenges that (potential) crises present. However, the possible preference for collectivist values in the research about glass-cliff is underexplored. 


\subsection{Women discrimination in top management positions}

The inequality of women in the labour world is very well reflected in the difficulty of many of them, in comparison to men, to pursue a career that would lead them to positions of responsibility in government or private companies. In fact, women rarely reach the top, and get stuck in jobs that are below their potential.

This invisibility in leadership and decision-making positions has led to different authors $[5,6,7,8]$ as well as government agencies [9], show and denounce the existence of so-called glass ceiling. This term is a metaphor that refers to the "invisible" barriers that women face in most organizations when trying to access management positions [10]. These barriers prevent many women with personal and professional capacity to positions in management environments and promoted within them [11, 12]. The most important barriers include the occupational segregation and employment discrimination. However, there is an especially relevant factor in understanding why the glass ceiling appears. We refer to the influence of gender stereotypes [13]. In fact, the glass ceiling is actually a result of gender stereotypes and the expectations they generate on how women behave and how should behave in leadership positions [14].

Moreover, the scarce number of women that leaves behind low and middle management jobs and reaches top management positions, still copes with another form of discrimination, the so-called glass cliff [2]. It alludes to the fact that women are often appointed to positions that are more unstable, and associated with greater chance of failure than those occupied by men [2, 3, 4]. In the recent years, empirical evidence demonstrates and replicates it in several contexts as well as in different countries [15]. Individuals prefer to select women to lead under struggling conditions but like better men to lead in more thriving situations $[16,17]$.

Growing literature analyses the processes underlying glass cliff, and the explanation that has received the most attention from researchers is gender stereotypes [14]. Women are considered better crisis managers, since it is assumed that they have the communal attributes which seems to be particularly useful in times of crisis or risk rather than the agentic ones.

\subsection{Individualistic vs. collectivist values}

Values are broad goals that vary in importance as guiding principles in life of people. Two types are distinguished: collectivistic and individualistic values. They differ on their emphasis on a collective or personal self, if personal goals are considered more or less important than the group goals, and the extent to which social norms or individual attitudes should determine behavior [18]. Values that serve individualistic interests are ambition or pleasure, while values that serve collectivist interests are, for instance, responsibility or helpfulness The next table summarizes some common contrasts in collectivistic vs. individualistic values [19].

Table 1. Contrasts in emphasis between common collectivistic and individualistic values

\begin{tabular}{c|c|}
\hline Collectivistic values & Individualistic values \\
\hline Interdependence & Independence \\
\hline Obligations to others & Individual rights \\
\hline Rely on group & Self-sufficiency \\
\hline Adhere to traditional values & True to own values and beliefs \\
\hline Maintain traditional practices & Continuously improve practices (progress) \\
\hline Fulfill roles within group & Pursue individual goals/interests \\
\hline Group achievement & Individual achievement \\
\hline Competition between groups & Competition between individuals \\
\hline Group or hierarchical decision-making & Self-determination and individual choice \\
\hline Shame/guilt due to failing group & Shame/guilt due to individual failure \\
\hline Living with kin & Independent living \\
\hline Take care of own & Seek help if needed \\
\hline Property shared within group & Strong individual property rights \\
\hline Objects valued for social uses & Objects valued for technological uses \\
\hline
\end{tabular}


Traditionally, research on gender issues has displayed that the values that serve to collectivist interests are consistent with the traditional feminine gender role, while the values that serve to individualistic interests are consistent with the traditional masculine. In a review about leadership styles and gender it is concluded that women have distinctive values (i.e., connection or collaboration) [1].

In addition, stereotypically female values are not congruent with the values traditionally associated to leadership positions [1]. The masculine ones seem to be more suitable. As result, women may have difficulties to achieve leadership jobs in comparison with men (think manager-think male). However, when we think about a company which is performing poorly, that is to say, is in a crisis situation, which values are preferred in the leader, the masculine or the feminine ones? The possible preference for collectivist values is underexplored in glass-cliff research. What we know is that the women preference for collectivistic values leads them to show a more transformational leadership style. In fact, this kind of style is more likely that appears in crisis time [20,21].

In this context, this study is conducted with the aim of analysing which values are considered more suitable in a leader in an organization which is facing a crisis and also to explore the gender differences in this topic.

\section{METHODOLOGY}

\subsection{Sample and procedure}

The sample was composed of 240 university students from several degree courses in Spain. There were 144 females $(60 \%)$ and 96 males $(40 \%)$, aged between 20 and 50 years (mean $=23.58, S D=$ 3.69). These students completed the instruments of the study in groups of three in the laboratory under the guidance of a member of the research team, who explained the content of the scales and cleared up any possible doubts. Confidentiality of their responses was fully guaranteed.

\subsection{Variables and measures}

The variables analysed in the students were the following:

- Gender. Male - female.

- Age. Years old.

- Human values. The participants were asked to indicate how much several human values were suitable to the performance of a top managerial position in a crisis company on a 7-point scale ranging from 1 (totally disagree) to 7 (totally agree). The values were 18 items that make up the Schwartz Value Survey (SVS) [22], adapted and validated in Spain [23]. The values were 11 individualistic (i.e., power, wealth, self-respect, social recognition, authority, independence, ambition, bold, influential, capability, success), and 7 collectivistic (i.e., make sense in life, loyalty, obedience, helpfulness, responsibility, self-discipline, friendship) character [1]. Individualistic values subscale $\alpha$ de Cronbach $=.77$ and collectivistic values subscale $\alpha$ de Cronbach $=.71$.

\subsection{Data analyses}

Data analysis was performed using the SPSS statistics computer program. Descriptive analysis, correlations (Pearson's r), and internal consistencies (Cronbach's $\alpha$ ) were performed. In order to achieve the first study objective, one $t$ test was carried out where the mean score of individualistic values was compared to the mean score of collectivistic values. Secondly, we performed an ANOVA in which the factor was gender and the dependent variables were individualistic and collectivistic values. Also we did an ANOVA for each human value.

\section{RESULTS}

The Table 1 shows the means, standard deviations (SD), internal consistencies (Cronbach's $\alpha$ ), and the correlations of the study variables. The mean scores revealed that this sample considered the individualistic and collectivistic values moderately suitable for performing a managerial job in a crisis company. Individualistic and collectivistic values subscales were sufficiently consistent internally, since 
Cronbach's $\alpha$ met the criterion of 0.70 [24]. As we can see at Table 1, gender correlated positively with collectivistic values. As well, individualistic values correlated positively with collectivistic values.

In addition, the results of $t$ test showed $\{t(238,1)=-.177, p=.86\}$, in global terms, that individualistic values mean score $(M=5.54, S D=0.63)$ was not significantly higher than collectivistic values mean score $(\mathrm{M}=5.51, \mathrm{SD}=0.72)$.

Table 1: Means, standard deviations, internal consistencies (Cronbach's $\alpha$ ), and correlation (Pearson $r$ )

\begin{tabular}{l|c|c|c|c|c|c}
\hline Variables & Mean & SD & $\alpha$ & 1 & 2 & 3 \\
\hline 1- Gender & - & - & - & - & - & - \\
\hline 2- Age & 23.5 & 3.69 & - & -.023 & - & - \\
\hline 3- Individualistic values & 5.54 & .63 & .77 & .012 & .10 & - \\
\hline 4- Collectivistic values & 5.51 & .72 & .71 & $.16^{*}$ & .11 & $.30^{* *}$ \\
\hline
\end{tabular}

${ }^{*} \mathrm{p}<.05{ }^{* *} \mathrm{p}<.01$

Table 2: Means, standard deviations of human values

\begin{tabular}{l|c|c|l|c|c}
\hline Individualistic values & Mean & SD & Collectivistic values & Mean & SD \\
\hline Power & 5.12 & 1.33 & Make sense in life & 6.02 & .97 \\
\hline Wealth & 3.85 & 1.57 & Loyalty & 5.17 & 1.40 \\
\hline Self-respect & 6.20 & .87 & Obedience & 5.43 & 1.34 \\
\hline Social recognition & 5.63 & 1.06 & Helpfulness & 5.33 & 1.29 \\
\hline Authority & 5.83 & 1.07 & Responsibility & 6.39 & .73 \\
\hline Independence & 5.16 & 1.44 & Self-discipline & 5.96 & 1.07 \\
\hline Ambition & 5.93 & 1.01 & Friendship & 4.52 & 1.47 \\
\hline Bold & 4.74 & 1.31 & & & \\
\hline Influential & 5.67 & 1.16 & & & \\
\hline Capability & 6.40 & .70 & & & \\
\hline Success & 6.44 & .77 & & & \\
\hline
\end{tabular}

In particular, as Table 2 displays, the more preferred personal values in order to perform accurately a top management position in a crisis organization were: success, capability, and self-respect (individualistic items), and responsibility and make sense in life (Collectivistic items). On the contrary, wealth (Individualistic item) was the less appreciated value for a power and responsibility job in a crisis context.

The results of the ANOVA displayed in Table 3 show that male and female students preferred in a similar way individualistic values. In the case of collectivistic values, female students preferred them to a greater extent in comparison with male students.

Table 3: Summary of ANOVA. Differences in Personal attributes depending on sample gender

\begin{tabular}{l|c|c|c|}
\hline Main variables & $\begin{array}{c}\text { Mean score of males } \\
\mathrm{N}=96\end{array}$ & $\begin{array}{c}\text { Mean score of } \\
\text { females N=144 }\end{array}$ & $\mathrm{p}$ \\
\hline Individualistic values & 5.53 & 5.54 & .86 \\
\hline Collectivistic values & 5.40 & 5.64 & .014 \\
\hline
\end{tabular}

Finally, as we can see in Table 4, we found gender differences in the Individualistic items of power, social recognition, and capability. Male university students considered power more appropriate for top management in a crisis situation than female students. In relation to social recognition and capability, female students obtained higher scores than their peers. 
Also we obtained gender differences in several collectivistic values: make sense in life, obedience, helpfulness, and responsibility. In all the cases, female university students perceived these values more appropriate for top management in a crisis situation than their peers.

Table 4: Summary of ANOVA. Differences in the different personal attribute items depending on sample gender

\begin{tabular}{l|c|c|c|l|c|c|c|}
\hline Individualistic values & $\begin{array}{c}\text { Mean } \\
\text { males } \\
\text { score } \\
\mathrm{N}=96\end{array}$ & $\begin{array}{c}\text { Mean } \\
\text { female } \\
\text { s score } \\
\mathrm{N}=144\end{array}$ & $\mathrm{p}$ & Collectivistic values & $\begin{array}{c}\text { Mean } \\
\text { males } \\
\text { score } \\
\mathrm{N}=96\end{array}$ & $\begin{array}{c}\text { Mean } \\
\text { female } \\
\text { s score } \\
\mathrm{N}=144\end{array}$ & $\mathrm{p}$ \\
\hline Power & 5.35 & 1.23 & .024 & Make sense in life & 5.82 & 6.15 & .012 \\
\hline Wealth & 3.90 & 3.82 & .71 & Loyalty & 5.10 & 5.21 & .57 \\
\hline Self-respect & 6.11 & 6.26 & .22 & Obedience & 5.17 & 5.61 & .012 \\
\hline Social recognition & 5.42 & 5.78 & .010 & Helpfulness & 5.00 & 5.55 & .001 \\
\hline Authority & 5.94 & 5.76 & .20 & Responsibility & 6.27 & 6.47 & .036 \\
\hline Independence & 5.14 & 5.17 & .84 & Self-discipline & 5.93 & 5.99 & .68 \\
\hline Ambition & 5.97 & 5.90 & .58 & Friendship & 4.54 & 4.51 & .89 \\
\hline Bold & 4.66 & 4.79 & .46 & & & & \\
\hline Influential & 5.7 & 5.62 & .42 & & & & \\
\hline Capability & 6.28 & 6.47 & .046 & & & & \\
\hline Success & 6.32 & 6.51 & .061 & & & & \\
\hline & & & & & & & \\
\hline
\end{tabular}

\section{CONCLUSIONS}

The aim of this study was to analyze which values are considered more suitable in a leader in an organization which is facing a crisis and also to explore the gender differences in this topic. Regarding the first objective, the findings display that, in general terms, this sample consider that both individualistic and collectivistic values are moderately suitable for performing a managerial job in a crisis company. Specifically, the more preferred personal values in order to perform accurately a top management position in a crisis organization are: success, capability, and self-respect (individualistic items), and responsibility and make sense in life (collectivistic items). On the contrary, wealth (individualistic item) was the less appreciated value for a power and responsibility job in a crisis context.

As well, the results show that male and female students prefer in a similar way individualistic values. In the case of collectivistic values, female students prefer them to a greater extent in comparison with male students. In addition, we find gender differences in the Individualistic items of power, social recognition and capability. Male university students consider power more appropriate for top management in a crisis situation than female students. In relation to social recognition and capability, female students obtain higher scores than their peers. Also we obtain gender differences in several collectivistic values: make sense in life, obedience, helpfulness, and responsibility. In all the cases, female university students see these values more appropriate for top management in a crisis situation than their peers.

Our findings do not support the idea of preferring collectivistic values in poor performance contexts, since both individualistic and collectivistic values are appreciated in a similar way. What we obtain is that clearly women are not interested in power. This could prejudice their promotion, training, and career plans to become top managers. As well, female students clearly prefer collectivistic values. These values are closer to coaching and transformational leadership, the notion of transformational leader [25]. However, a dangerous result is the fact that female students value obedience to a greater extent than male students. This implies that still women assume supporting roles, not starring roles. This evidences the validity of gender stereotyping reflected also in the validity of traditional values, that places women in middle positions, where they have to obey. If women value obedience, themselves they are hindering the way to be top managers. 
Values guide attitudes and behaviors. Values contribute to action to the extent that they are relevant in the context (hence likely to be activated) and important to the actor. [22]. Education could be a powerful means to inculcate values among students. Those values should promote equality between men and women in all life spheres, included management.

\section{ACKNOWLEDGEMENTS}

This research is supported by a grant from the Spanish Ministry of Health, Social Services and Equality (2011-0004-INV-00014).

\section{REFERENCES}

[1] Cuadrado I. (2004). Valores y rasgos estereotípicos de género de mujeres líderes. Psicothema 16, pp. 279-284.

[2] Ryan, M.K., \& Haslam, S.A. (2005). The glass cliff: Evidence that women are over-represented in precarious leadership positions. British Journal of Management, 16, pp. 81-90.

[3] Haslam, S. A., \& Ryan, M. K. (2008). The road to the glass cliff: Differences in the perceived suitability of men and women for leadership positions in succeeding and failing organizations. Leadership Quarterly, 19, pp. 530-546.

[4] Ryan, M. K. \& Haslam, S. A. (2007). The glass cliff: Exploring the dynamics surrounding women's appointment to precarious leadership positions. Academy of Management Review, 32, pp. 549-572.

[5] Chernesky, R. H. (2003). Examining the glass ceiling: Gender influences on promotions decisions. Administration in Social Work 27, pp. 13-18.

[6] Powell, G. N. (1999). Reflections on the ceiling glass. Recent trend and future prospects. In G. N. Powell (ed.): Handbook of gender and work. Sage Publications. Thousand Oaks, CA.

[7] Reid, M., Miller, W. \& Kerr, B. (2004). Sex-Based Glass Ceilings in U.S. State-Level Bureaucracies, 1987-1997. Administration \& Society, 36(4), pp. 377-405.

[8] van Vianen, A. E. M. \& Fischer, A. H. (2002). Illuminating the glass ceiling: The role of organizational culture preferences. Journal of Occupational and Organizational Psychology 75, pp. 315-337.

[9] ILO (2004). Romper el techo de cristal. Las mujeres en puestos de dirección. Actualización 2004. Geneva: International Labour Organization. Retrieved from:

http://www.ilo.org/dyn/gender/docs/RES/292/F61986410/Romper\%20el\%20techo\%20de\%20cri stal.pdf

[10] Barreto, M., Ryan, M. \& Schmitt, M. T. (2009). Introduction: Is the glass ceiling still relevant on the $21^{\text {st }}$ century? In The glass ceiling in the 21 st century: Understanding barriers to gender inequality American Psychological Association. Washington, DC.

[11] Morrison, A. M. White, R. P. \& van Velsor, E. (1987). Breaking the glass ceiling. AddisonWesley. Readin.

[12] Sarrió, M., Barberá, E., Ramos, A. \& Candela, C. (2002). El techo de cristal en la promoción profesional de las mujeres. Revista de Psicología Social 17(2), pp. 167-182.

[13] Heilman, M. E. (2001). Description and prescription: How gender stereotypes prevent women's ascent up the organizational ladder. Journal of Social Issues 57, pp. 657-674.

[14] Worchel, S., Cooper, J., Goethals, G. R. \& Olson, J. M. (2003). Psicología social. Thomsom Madrid.

[15] Bruckmüller, S., Ryan, M. K., Rink, F. \& Haslam, S.A. (2014). Beyond the Glass Ceiling: The Glass Cliff and Its Lessons for Organizational Policy. Social Issues and Policy Revie, 8, pp. 202232.

[16] Bruckmüller, S., \& Branscombe, N. R. (2010). The glass cliff: When and why women are selected as leaders in crisis contexts. British Journal of Social Psychology, 49, pp. 433-451. 
[17] Rink, F., Ryan, M. K., \& Stoker, J. I. (2013). Clarifying the precariousness of the glass cliff: How social resources and gender stereotypes affect the evaluation of leaders in times of crisis. European Journal of Social Psychology, 43, pp. 381-392.

[18] Triandis, H. C. (1995). Individualism and collectivism. Boulder, CO: Westview Press.

[19] Leake, D. \& Black R. (2005). Essential tools. Cultural and Linguistic Diversity: Implications for Transition Personnel. ICI Publications Office. Minneapolis, MN. http://www.ncset.org/publications/essentialtools/diversity/EssentialTools_Diversity.pdf.

[20] Bass, B. M. (1990). Bass \& Stogdill's Handbook of Leadership: Theory, research and managerial applications. New York: Free Press.

[21] Pillai, R. (1996). Crisis and the emergence of charismatic leadership in groups: an experimental investigation. Journal of Applied Social Psychology, 26, 543-562.

[22] Schwartz, S. H. (1992). Universal in the content and structure of values: Theoretical advances and empirical test in 20 countries. En M. Zanna (ed.), Advances in Experimental Social Psychology, vol. 25 (pp. 1-65). New York: Academic Press.

[23] Ros, M. \& Grad, H. (1991). El significado del valor trabajo como relacionado a la experiencia ocupacional: Una comparación de profesores de EGB y estudiantes del CAP. Revista de Psicología Social, 6, pp. 181-208.

[24] Nunnaly, J. C. (1978). Psychometric Theory. McGraw-Hill. New York.

[25] Eagly, A. H. \& Sczesny, S. (2009). Stereotypes about women, men, and leaders: Have times changed? In M. Barreto, M. Ryan, \& M. T. Schmitt (eds.): The glass ceiling in the 21st century: Understanding barriers to gender inequality American Psychological Association. Washington, DC. 